\title{
Effects of climate and snow depth on Bromus tectorum population dynamics at high elevation
}

\author{
Alden B. Griffith • Michael E. Loik
}

Received: 22 January 2010/ Accepted: 30 July 2010/Published online: 26 August 2010

(C) The Author(s) 2010. This article is published with open access at Springerlink.com

\begin{abstract}
Invasive plants are thought to be especially capable of range shifts or expansion in response to climate change due to high dispersal and colonization abilities. Although highly invasive throughout the Intermountain West, the presence and impact of the grass Bromus tectorum has been limited at higher elevations in the eastern Sierra Nevada, potentially due to extreme wintertime conditions. However, climate models project an upward elevational shift of climate regimes in the Sierra Nevada that could favor B. tectorum expansion. This research specifically examined the effects of experimental snow depth manipulations and interannual climate variability over 5 years on $B$. tectorum populations at high elevation $(2,175 \mathrm{~m})$. Experimentally-increased snow depth had an effect on phenology and biomass, but no effect on individual fecundity. Instead an experimentally-increased snowpack inhibited population growth in 1 year by reducing seedling emergence and early survival. A similar negative effect of increased snow was observed 2 years later. However, a strong negative effect on B. tectorum was also associated with a naturally low-snow winter, when seedling emergence was reduced by $86 \%$. Across 5 years,
\end{abstract}

Communicated by Jon Keeley.

Electronic supplementary material The online version of this article (doi:10.1007/s00442-010-1749-3) contains supplementary material, which is available to authorized users.

A. B. Griffith · M. E. Loik

Environmental Studies Department, University of California,

Santa Cruz, CA 95064, USA

A. B. Griffith $(\bowtie)$

Wellesley College Botanic Gardens, Wellesley College,

106 Central Street, Wellesley, MA 02481, USA

e-mail: agriffit@wellesley.edu winters with greater snow cover and a slower accumulation of degree-days coincided with higher $B$. tectorum seedling density and population growth. Thus, we observed negative effects associated with both experimentally-increased and naturally-decreased snowpacks. It is likely that the effect of snow at high elevation is nonlinear and differs from lower elevations where wintertime germination can be favorable. Additionally, we observed a doubling of population size in 1 year, which is alarming at this elevation.

Keywords Climate change - Invasive - Sierra Nevada · Periodic matrix model $\cdot$ Snow fence

\section{Introduction}

Anthropogenic climate change is anticipated to affect the margins of species and population ranges, and there is extensive evidence that indicates this is already occurring (Parmesan and Yohe 2003; Root et al. 2003; Parmesan 2006). Range expansions and contractions may be particularly pronounced along elevational gradients where local climates change rapidly across small spatial scales. Wintertime conditions and snowpack dynamics at higher elevations can substantially affect organisms, and changes in these climatic factors may favor some species and hinder others (Billings and Bliss 1959; Dunne et al. 2003; Klanderud and Birks 2003; Pauli et al. 2007). In particular, the ability of terrestrial plants to respond to climate change may be highly variable among species due to large variation in life histories and dispersal abilities (Walther 2004).

Invasive plant species may be especially capable of rapid range shifts or expansion in the face of climate change because of generally high dispersal abilities and a proven ability to thrive in new habitats (Dukes and Mooney 
1999; Walther 2000; Walther et al. 2002). The rate of anthropogenic climate change is expected to be far greater than previous natural climatic changes, and dispersal ability will be crucial for plants to follow suitable climates (Simberloff 2000). Many invasive plants also exhibit short juvenile periods with high fecundity, and may be able to respond rapidly to climate change at the population level (Dukes and Mooney 1999; Simberloff 2000; Theoharides and Dukes 2007). It is therefore important to understand how climatic variables affect invasive plant populations at the edge of their elevational distribution.

The invasive annual grass Bromus tectorum L. (Poaceae; 'cheatgrass', 'downy brome') has profoundly altered ecosystems and fire regimes across the Great Basin Desert and Intermountain West (Billings 1990; D'Antonio and Vitousek 1992; Knapp 1996). It is estimated that areas invaded by $B$. tectorum are up to 500 times more likely to burn than native communities (BLM 2000). At higher elevations in the western Great Basin and eastern Sierra Nevada, the impact has been limited. However, the potential for plant invasions at high elevation has recently attracted attention (Pauchard et al. 2009) and B. tectorum populations are common along the base of the eastern Sierra Nevada escarpment (personal observation). Previous research has demonstrated that cold temperatures and winter snowfall can negatively impact B. tectorum survival, growth, and fecundity (Mack and Pyke 1983; Pierson and Mack 1990a; Chambers et al. 2007), which may help explain its limited presence in the eastern Sierra Nevada. While there remains uncertainty, several future climate scenarios for eastern California predict an upward elevational shift of climate regimes (Hayhoe et al. 2004; Leung et al. 2004; Snyder and Sloan 2005; Cayan et al. 2008). Under these scenarios, a release from climatic constraints could facilitate the invasion of $B$. tectorum into higher elevations in the Sierra Nevada.

Compared to research in alpine/subalpine and arctic/ subarctic systems, there has been relatively little work that examines the effect of wintertime snowpack on winter annuals, such as B. tectorum, at high elevation. Winter snowpack can exert both positive and negative influences on plant populations and communities depending on snow depth, melt timing, and snowpack duration (Billings and Bliss 1959; Bell and Bliss 1979; Jackson and Bliss 1984; Smith et al. 1995; Walker et al. 1995; Inouye et al. 2002). For B. tectorum, the timing of germination and environmental influences on germination can be variable (Mack and Pyke 1983, 1984; Beckstead et al. 1996; Meyer et al. 1997), and may further complicate the effects of snowpack dynamics.

The underlying question addressed by this study is whether winter snowpack limits the expansion of B. tectorum into high-elevation habitats. Specifically, we tested the hypotheses that (1) an experimentally-increased snowpack would negatively affect $B$. tectorum demographic rates and population growth, and (2) that winters with naturally deep and long-lasting snowpacks would have similar negative effects on demographic rates and population growth, in contrast to patterns following more mild winters. Our approach utilized experimental snowpack manipulations to isolate effects associated with winter conditions, and used this information to better understand the population-level response to natural climate variability among years. We conducted our research on a B. tectorum population at $2,175 \mathrm{~m}$ in elevation, typical of those established along the base of the eastern Sierra Nevada. We chose to primarily investigate demographic responses because of the specific relevance to the potential expansion and persistence of invasive species near the range margin.

\section{Materials and methods}

\section{Study system}

Research was conducted in a Great Basin Desert shrubland ecosystem adjacent to the Valentine Eastern Sierra University of California Natural Reserve (VESR) near Mammoth Lakes, CA $\left(37^{\circ} 36^{\prime} 51^{\prime \prime} \mathrm{N}, 118^{\circ} 49^{\prime} 47^{\prime \prime} \mathrm{W}, 2,175 \mathrm{~m}\right.$ elevation). Annual precipitation at the site is roughly $325 \mathrm{~mm}$ year $^{-1}$, and occurs mostly as snow during the winter. Surface soils at this site $(0-100 \mathrm{~cm}$ deep) are composed of sandy loam and gravelly sandy loam, are slightly acidic $(\mathrm{pH}=6.0)$, and are underlain by glacial alluvium deposits. The site is dominated by the native shrubs Artemisia tridentata Nutt. (Asteraceae; 'big sagebrush') and Purshia tridentata (Pursh) DC (Rosaceae; 'antelope bitterbrush'). Other, less common, shrubs include Chrysothamnus nauseosus and Prunus andersonii. Native perennial bunchgrasses are scattered and include Achnatherum hymenoides, Elymus elymoides, and Hesperostipa comata. Other herbaceous species include Gayophytum diffusum, Phacelia bicolor, Viola purpurea, and Eriastrum sparsiflorum. The site has been annually grazed for 1 month during the summer for at least 50 years (Dan Dawson, personal communication) with an average density of less than 0.25 calf/cow pairs ha $^{-1}$. During the period of this study, grazing occurred after B. tectorum senescence.

\section{Experimental design}

In October 2005, we constructed four experimental snow fences with the goal of manipulating snow depth in experimental plots (Online Resource 1). Each fence measured $30 \mathrm{~m}$ in length and $1.8 \mathrm{~m}$ in height and consisted of 16 vertical t-posts sunk $0.6 \mathrm{~m}$ into the ground. Plastic mesh 
fencing ( $50 \%$ porosity) was secured along the fence, leaving a 50-cm gap at the bottom (essential for proper snow fence functionality; Tabler 1991, 1994). This design allowed for the removal of the plastic fencing after each winter (April-October) to avoid the unwanted effects of shading and wind disruption during the growing season, although effects on wintertime wind scouring during snowfree periods remained possible. All fences were oriented perpendicular to the prevailing winter wind $\left(240^{\circ}\right)$ and remained in effect throughout the study.

Snow fences create zones of increased snow accumulation immediately downwind of the fence followed by an area of reduced snow accumulation farther downwind. Plots were established in the spring of 2005 at three snow fence sites prior to the snow manipulations to provide baseline information. Plots at the fourth snow fence were established in the spring of 2006 after the first snow manipulation winter. For each fence, plots were established downwind in association with areas of increased ( $2 \mathrm{~m}$ from each fence) and decreased (15 $\mathrm{m}$ from each fence) snow accumulation. Control plots were established both upwind (15 $\mathrm{m}$ from each fence) and farther downwind (40 $\mathrm{m}$ from each fence) where snow depth is unaffected by the fence. Two sets of control plots were deemed necessary as it is not possible to randomize the spatial order of snow manipulation plots. Within each snow depth treatment zone, we established sampling plots in association with three microhabitats: under adult $A$. tridentata canopies, under adult $P$. tridentata canopies, and in intershrub spaces. This is necessary to fully capture landscape-level population dynamics as microhabitat can significantly affect $B$. tectorum demography at this site (Griffith 2010). Plots varied in size in order to capture a sufficient number of $B$. tectorum individuals $(\geq 24)$ while remaining within each microhabitat (mean shrub microhabitat plot area $=480 \mathrm{~cm}^{2}$, mean intershrub plot area $=896 \mathrm{~cm}^{2}$ ).

Whereas our goal was to incorporate both increased and decreased snow accumulation treatments, the size of the snow fences was apparently not large enough to produce a significant reduction in snow accumulation (increased snow accumulation remained a robust treatment-see "Results"). In general, areas of snow reduction downwind of snow fences are much more spread out compared to the narrow and focused snow accumulation zone. Thus, we have excluded the reduced snow accumulation treatment from this study as there was not a robust treatment application nor can it be considered a true control. Also, there were never any significant effects on B. tectorum detected in these plots. The final experimental design presented in the paper thus includes four snow fences, each with zones designated as 'upwind control', 'downwind control', and '+snow', and three subplots (one in each microhabitat) within each snow manipulation zone.
Snow depth and climatic variables

Snow depth and cover were examined in three ways. First, snow depth in the experimental plots was manually measured monthly during winter, except for winters when there was no persistent snowpack. Second, daily modeled ambient snow depth and cover data were obtained from the National Operational Hydrologic Remote Sensing Center's (NOHRSC) KMMH station, which is less than $1 \mathrm{~km}$ from our research site. These values of snow depth are generated from an energy-and-mass-balance, multilayer snow model. Third, the percentage of days with snow cover for each winter was estimated from NOHRSC satellite observations. This was deemed necessary as the modeled snowpack data from 2008/2009 was in contrast to the observation of no persistent snowpack during that winter (this may be a result of difficulties in modeling the snowpack for a site near the elevational snow line). We estimated the percentage of snow cover days as a range, such that the low end includes days with satellite estimates of $60-100 \%$ snow cover. The high end is less conservative and includes days with 20-100\% snow cover.

We calculated total precipitation during the winter (defined as December 1-April 14) and the growing season (defined as April 15-June 30) from a permanent weather station at VESR. Accumulated degree-days were calculated between September 1 and April 14 using hourly air temperature and modeled snowpack data, such that degreedays accumulated only when air temperature was above zero and when the modeled snow depth was less than $1 \mathrm{~cm}$. We also calculated potential evapotranspiration (PET) during the growing season based on daily minimum and maximum temperature, relative humidity, solar radiation $(0.285-50 \mu \mathrm{m})$, and average wind speed using the Penman-Monteith method (Allen et al. 1998).

\section{Demographic sampling}

In this paper, we present two complementary and overlapping demographic datasets that examine the response of a naturally-occurring, high-elevation $B$. tectorum population to both experimental snow depth manipulations and to natural climatic variability. First, we used a 2-year detailed demographic dataset based on the complete life cycles of over 1,600 individual plants. These data were used to build matrix population models to better understand how the response of individuals translates into the response of the population. Second, we continued to monitor B. tectorum seedling density every April in these plots for 5 years (2005-2009) to provide a more long-term perspective on the population-level response to snow manipulations and natural climatic variation. 
The fates of $1,603 \mathrm{~B}$. tectorum individuals were monitored in demographic plots during the 2005 and 2006 growing seasons. Sampling was conducted twice in 2005 (28 April-May 1 and June 9-11), and three times in 2006 (April 25-27, May 12-14, and June 5-7). After measuring the density of B. tectorum in each plot in April, up to 24 individual plants were marked with uniquely identifiable toothpicks. These plants were measured for survivorship, number of leaves, length of the longest leaf, maximum culm height, and number of spikelets (in 2006, spikelets were not fully developed during the June sampling period, and we returned on June 26 to record the final spikelet counts). We also measured gravimetric soil moisture content at $15 \mathrm{~cm}$ depth adjacent to each plot during each sampling period.

Individual aboveground biomass was estimated by measuring (as above) and then harvesting 147 additional B. tectorum individuals from areas nearby demographic plots to avoid disturbance within the plots. Samples were weighed after drying for $96 \mathrm{~h}$ at $60^{\circ} \mathrm{C}$, and the data were used to estimate the biomass of individual plants in the field using allometric relationships ( $r^{2}=0.87$; Griffith 2010). Aboveground relative growth rates ( $\mathrm{RGR}, \mathrm{mg} \mathrm{mg}^{-1} \mathrm{day}^{-1}$ ) between sampling periods were calculated as, $\mathrm{RGR}=$ $\left(\ln\right.$ Biomass $_{2}-\ln$ Biomass $\left._{1}\right) /\left(t_{2}-t_{1}\right.$ ) (Hunt 1978).

To estimate seed production from non-destructive spikelet counts, we harvested a total of 118 plants adjacent to the experimental plots and counted the number of fertile florets per spikelet. An average value of 1.78 seeds per spikelet was assumed for all individuals as there were no significant differences among snow depth treatments $\left(F_{3,114}=2.08, P=0.107\right)$. The rate of seedling emergence was calculated as the density of established seedlings in April divided by the estimated seed output density from the previous year.

Statistical analysis and demographic modeling

To examine univariate differences among snow depth treatments within a year, we used a split-plot analysis of variance (ANOVA) that included the following factors: snow fence (random blocking effect, $n=4$ ), snow depth treatment (fixed effect, $n=3$ ), and microhabitat (fixed effect, $n=3$ ). $F$ ratios for both snow depth and microhabitat were calculated using their respective interactions with snow fence as the error term. We included the effect of microhabitat in the model to investigate possible interactions with snow depth, although the effect of microhabitat per se is not within the scope of this paper (see Griffith 2010). The snow depth by microhabitat interaction (using the 3-way interaction as the error term) was never significant for any response variable, and the effect of microhabitat was dropped from the model. The final statistical model therefore simplified to a block design, with snow fence as the block and snow depth treatment as the main factor (with each snow depth plot value an average of the three microhabitats within). We tested the hypothesis that increased snow depth would have a negative effect on B. tectorum demographic variables using a planned contrast of + snow plots against both sets of control plots. The $F$ ratio of the entire model is not an appropriate test as we would not expect there to be any differences between the two sets of control plots. To satisfy the assumptions of ANOVA, values of biomass, spikelet number, and $\lambda$ were log-transformed, and survivorship and establishment values were arcsin-square root transformed. Values of log-transformed variables presented in the paper have been subsequently back-transformed. All univariate analyses of the snow manipulations were performed using Systat (version 12, Systat Software, Point Richmond, CA, USA).

To examine differences in demographic variables due to natural variability between 2005/2006 and 2006/2007, we restricted our analyses to the snow depth control plots only (averaged across the three microhabitats). To statistically compare these 2 years, we used 2-sample, two-tailed randomization tests (Manly 1997; Caswell 2001) as no distributional assumptions are required. Changes in B. tectorum April seedling densities from 2005 to 2009 were calculated as April-to-April population growth rates $(\lambda)$, where $\lambda=N_{t+1} / N_{t}$. Mean values of $\lambda$ were calculated using log-transformed data.

We used periodic matrix models and life table response experiment (LTRE) analysis to estimate population growth $(\lambda)$ and to examine how differences in demographic vital rates contributed to differences in $\lambda$. The population model is described in detail by Griffith (2010), with the exception here that seed germination and establishment rates are parameterized from natural seedling emergence data. We used the LTRE analysis to specifically examine $\lambda$ differences among snow depth treatments (comparing +snow values to pooled values of control plots) and between years (using ambient snow depth plots only). All randomization tests and population modeling were conducted using Matlab (release 14, The Mathworks, Natick, MA, USA).

\section{Results}

Snow depth and soil moisture

During the first winter following the construction of the snow fences (2005/2006), average snow depth on +snow plots was consistently greater than on control plots (Fig. 1). The + snow snowpack remained substantial throughout the winter, whereas there was a measurable snowpack on 
control plots only on the January sampling date. The pattern was similar 2 years later in the 2007/2008 winter, with + snow plots having roughly twice the snow depth of control plots during periods of snow cover. During the 2006/2007 winter there was never a persistent snowpack in any plot due to low natural snowfall. Whereas sampled snow depth on control plots in the 2005/2006 and 2007/ 2008 winters was reasonably consistent with the NOHRSC modeled snowpack data (Fig. 1), on-site observations during the 2008/2009 winter were not consistent with the modeled snowpack in that virtually no persistent snowpack was observed in any plots that year.

Following the first winter of snow manipulations (the period in which we concurrently sampled detailed demographic parameters), soil moisture did not significantly vary among plots in April or June 2006 (Table 1). In May

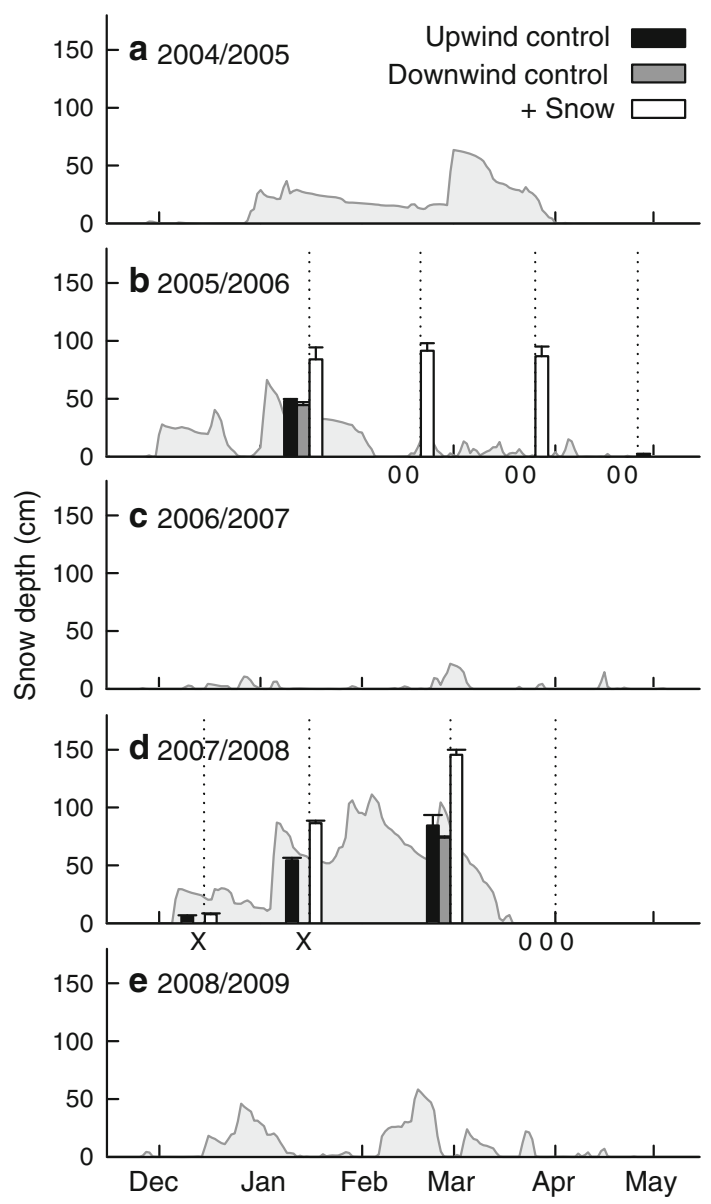

Fig. 1 Experimental snow depth and natural snowpack formation from 2004/2005 to 2008/2009. Gray areas depict NOHRSC modeled snow depth (see "Methods"). Vertical bars indicate the means + 1SE of manually-sampled snow depth in experimental plots during winters with a measureable snowpack (dashed lines sampling dates). 0 no snow cover, $X$ missing data. Snow fences were not yet in effect during the 2004/2005 winter. NOHRSC modeled snow depth in 2008/2009 conflicts with on-site observations of no persistent snowpack (see "Results")
Table 1 Soil gravimetric percent water content $(\Theta)$ at $15 \mathrm{~cm}$ depth following the 2005/2006 snow depth treatments

\begin{tabular}{llll}
\hline$\Theta$ & Upwind control & Downwind control & + Snow \\
\hline April & $7.51 \mathrm{a}$ & $8.43 \mathrm{a}$ & $8.41 \mathrm{a}$ \\
May & $4.63 \mathrm{~b}$ & $6.78 \mathrm{a}$ & $6.44 \mathrm{a}$ \\
June & $4.21 \mathrm{a}$ & $4.41 \mathrm{a}$ & $4.30 \mathrm{a}$ \\
\hline
\end{tabular}

Values are means; letters indicate significant differences $(P<0.05)$ among snow depth treatment levels as revealed by Tukey's HSD test

2006, soil moisture on +snow and downwind control plots was significantly greater than on upwind control plots (Table 1).

Experimental snow depth manipulation: detailed demography

During the 2006 growing season, mean individual biomass on +snow plots was significantly and consistently lower than on control plots (Table 2). Most spikelets were visible during the June sampling period, but spikelet production had not finished. Between the early June sampling period and the final spikelet counts in late June, additional spikelet production was significantly greater on + snow plots. The final spikelet counts revealed no significant differences among snow depth treatments in terms of total individual spikelets (Table 2). Thus, it appears that the timing of spikelet production was affected by an increased snowpack, but final individual reproductive output was not. Survivorship between sampling periods varied significantly among snow depth treatments, although this is likely due to a combination of shifted phenologies and fixed sampling dates (e.g., early mortality was likely captured on +snow plots but not controls; see "Discussion").

Demographic rates from 2006 were incorporated into a periodic matrix population model in order to examine a

Table 2 Bromus tectorum biomass and spikelet production following the 2005/2006 snow depth treatment

\begin{tabular}{lcllc}
\hline Response variable & $\begin{array}{l}\text { Upwind } \\
\text { control }\end{array}$ & $\begin{array}{l}\text { Downwind } \\
\text { control }\end{array}$ & & +Snow \\
\hline April biomass & 2.59 & 2.59 & $* * *$ & 1.73 \\
May biomass & 4.13 & 4.43 & $* *$ & 3.27 \\
June biomass & 28.4 & 27.8 & $* * *$ & 19.4 \\
RGR (Apr-Jun) & 0.058 & 0.058 & NS & 0.056 \\
June spikelets & 3.48 & 3.47 & $*$ & 2.54 \\
Late spikelet production & 0.22 & 0.05 & $* * *$ & 1.37 \\
Final (July) spikelets & 3.73 & 3.52 & NS & 4.03 \\
\hline
\end{tabular}

Values are means; significant differences between + snow and control plots: $* P<0.05, * * P<0.01, * * * P<0.001$

$N S$ indicates non-significance

Biomass in mg, RGR in $\mathrm{mg} \mathrm{mg}^{-1}$ day $^{-1}$ 


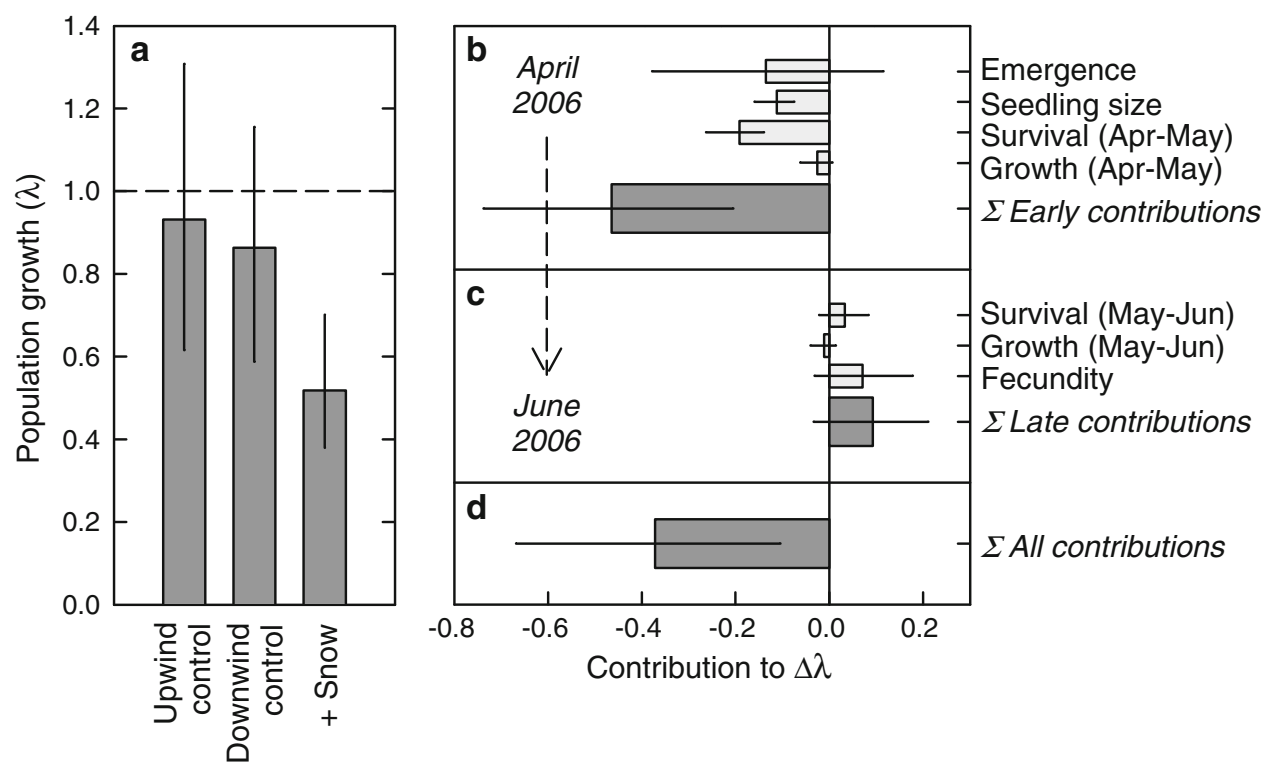

Fig. 2 Results from the periodic population model of Bromus tectorum comparing snow depth treatment effects in 2006 on a modeled population growth rates (means $\pm 95 \% \mathrm{CI}$ ). The life table response experiment (LTRE) analysis is separated into contributions from $\mathbf{b}$ demographic rates primarily influenced by the snowpack and immediate post snow melt environment, c those primarily influenced by growing season conditions, and $\mathbf{d}$ the total

more synthetic response to the snow manipulation. Modeled population growth $(\lambda)$ was significantly reduced on + snow plots $(P=0.013)$, with no overlap of the $95 \%$ confidence intervals and $\lambda=1.0$ (Fig. 2a). The life table response experiment (LTRE) analysis revealed how differences in vital rates between + snow plots and control plots (pooled) contributed to the decrease in $\lambda$ on + snow plots (Fig. $2 \mathrm{~b}-\mathrm{d}$ ). The reduction of $\lambda$ on + snow plots was primarily due to reduced demographic rates associated with initial seedling size, seedling emergence, and early survival, i.e. effects immediately following snowmelt. Demographic rates occurring later in the growing season (May-June survival, growth, and fecundity) were not different among snow depth treatments and thus did not contribute to the low $\lambda$ on + snow plots.

Experimental snow depth manipulation: long-term density

Prior to the construction of the snow fences there was no difference in B. tectorum densities among plots (Fig. 3). After the snow fences were installed, mean seedling densities on +snow plots were generally lower than on control plots, but there was no difference in April 2009. Statistically, differences between + snow and control plots were marginally significant in June $2006\left(F_{1,6}=3.773\right.$, summed contributions of all effects (mean contributions $\pm 95 \% \mathrm{CI}$ ). More negative values indicate a greater contribution to the decrease in $\lambda$ on + snow plots. Separate contributions from April-May survival and seedling emergence cannot be accurately interpreted due to shifted phenology on + snow plots, but their combined sum remains accurate (see "Discussion")

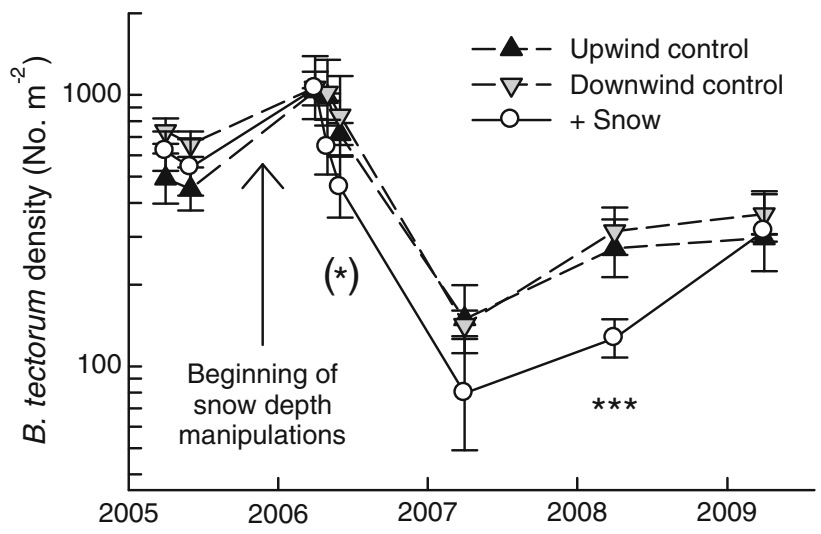

Fig. 3 Changes in Bromus tectorum densities in response to experimental snow depth treatments. Values are means \pm 1 SE (sample size varied depending on treatment and year-see text for details). Sampling occurred in late April of every year, June 2005, and May and June 2006. Significant differences between + snow and control plots: $* * * P<0.001,(*) 0.05<P<0.10$

$P=0.100)$ and highly significant in April $2008\left(F_{1,6}=\right.$ 40.60, $P<0.001)$.

Natural interannual variability: detailed demography

The detailed demography dataset captured the natural variation of B. tectorum over two full years, from April 2005 to April 2007 (beginning and ending as seedlings). 
Table 3 Values of response variables in 2005/2006 and 2006/2007 (snow depth control plots only)

\begin{tabular}{lllc}
\hline Response variable & $2005 / 2006$ & & $2006 / 2007$ \\
\hline April soil $\Theta$ & 7.40 & NS & 7.97 \\
June soil $\Theta$ & 3.58 & NS & 4.31 \\
April biomass & 3.28 & $* *$ & 2.59 \\
June biomass & 45.9 & $* * *$ & 28.1 \\
RGR (Apr-Jun) & 0.063 & $(*)$ & 0.058 \\
Seedling emergence & 0.19 & $* * *$ & 0.04 \\
Survivorship (Apr-Jun) & 0.88 & $(*)$ & 0.76 \\
Spikelets & 6.32 & $* * *$ & 3.63 \\
\hline
\end{tabular}

Values are means; significant differences: $* * P<0.01$, $* * * P<0.001$, (*)0.05 $<P<0.10$

$N S$ non-significance

Biomass in $\mathrm{mg}$, RGR in $\mathrm{mg} \mathrm{mg}^{-1} \mathrm{day}^{-1}$

Thus, each year included responses associated with different wintertime and growing-season conditions. Most demographic variables on unmanipulated, snow depth control plots were significantly different between years (Table 3). During the growing season, individual biomass (in April and June), and spikelet number were significantly greater in 2005 compared to 2006. A reduction in Aprilto-June RGR between 2005 and 2006 was marginally significant $(P=0.060)$. Similarly, decreased survivorship between 2005 and 2006 was marginally significant $(P=0.068)$. The mean emergence/establishment rate in $2005 / 2006$ was $18.6 \%$ compared to $4.0 \%$ in $2006 / 2007$. The timing of germination events and seedling establishment also apparently varied between years. In 2005 and 2006, there was no evidence of germination prior to April snowmelt. However, in April 2007, less than 2\% of individuals were substantially larger than all previously measured seedlings, presenting two discrete seedling size class classes indicative of two cohorts that germinated at different times (data not shown).
Modeled $\lambda$ was significantly greater $(P<0.001)$ in $2005 / 2006(\lambda=1.85)$ compared to $2006 / 2007(\lambda=0.23$; Fig. 4a). LTRE analysis was used to examine differences in $\lambda$ on control plots for these two annual periods (Fig. 4b). The decrease in seedling emergence rates between 2005/ 2006 and 2006/2007 accounted for 63\% of the decrease in $\lambda$. Differences in fecundity, growth, and survival further accounted for $21,8.9$, and $6.8 \%$ of the decrease in $\lambda$, respectively. Thus, similar to the snow depth LTRE analysis, the greatest contribution to the decrease in $\lambda$ was associated with effects on early life history stages compared to those later in the growing season.

Natural interannual variability: long-term density

From 2005 to 2009 , B. tectorum density fluctuated greatly on control plots (Fig. 3). Positive population growth $\left(\lambda=N_{t+1} / N_{t}\right)$ was observed during $2005 / 2006(\lambda=1.67)$, $2007 / 2008(\lambda=2.03)$, and $2008 / 2009(\lambda=1.12)$. These years contrasted with the precipitous population decline between 2006 and $2007(\lambda=0.14)$. Spanning the 5 years of sampling in April, B. tectorum seedling density on snow depth control plots was positively correlated with the antecedent winter's (December 1 to April 14) total precipitation $\left(r^{2}=0.85, P=0.025\right.$; Fig. 5a) and percentage of days with snow cover $\left(r^{2}=0.80, P=0.040\right.$; Fig. $\left.5 b\right)$. The relationship between seedling density and accumulated degree-days was marginally significant $\left(r^{2}=0.69\right.$, $P=0.082$; Fig. 5c). April seedling density did not correlate with potential evapotranspiration or total precipitation of the antecedent growing season.

Compared to density measurements, annual population growth of seedlings (April-to-April $\lambda$ ) did not significantly correlate with any climatic variables (Fig. $5 f-j$ ). However, as statistical power with only four data points is low, strong but nonsignificant relationships emerged between Aprilto-April $\lambda$ and the percentage of days with snow cover
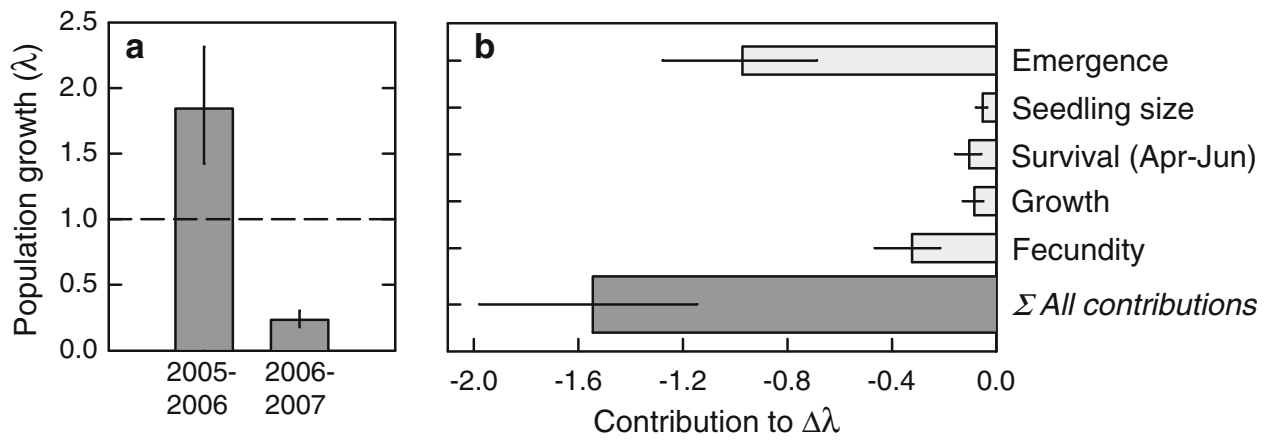

Fig. 4 Results from the periodic population model and LTRE analysis of Bromus tectorum, comparing natural variability between $2005 / 2006$ and 2006/2007. a Modeled population growth rates (means $\pm 95 \%$ CI) among years, b contributions of changes in demographic rates to the decrease in $\lambda$ between years (mean contributions $\pm 95 \% \mathrm{CI}$ ). More negative values indicate a greater contribution to the observed decrease in $\lambda$ 


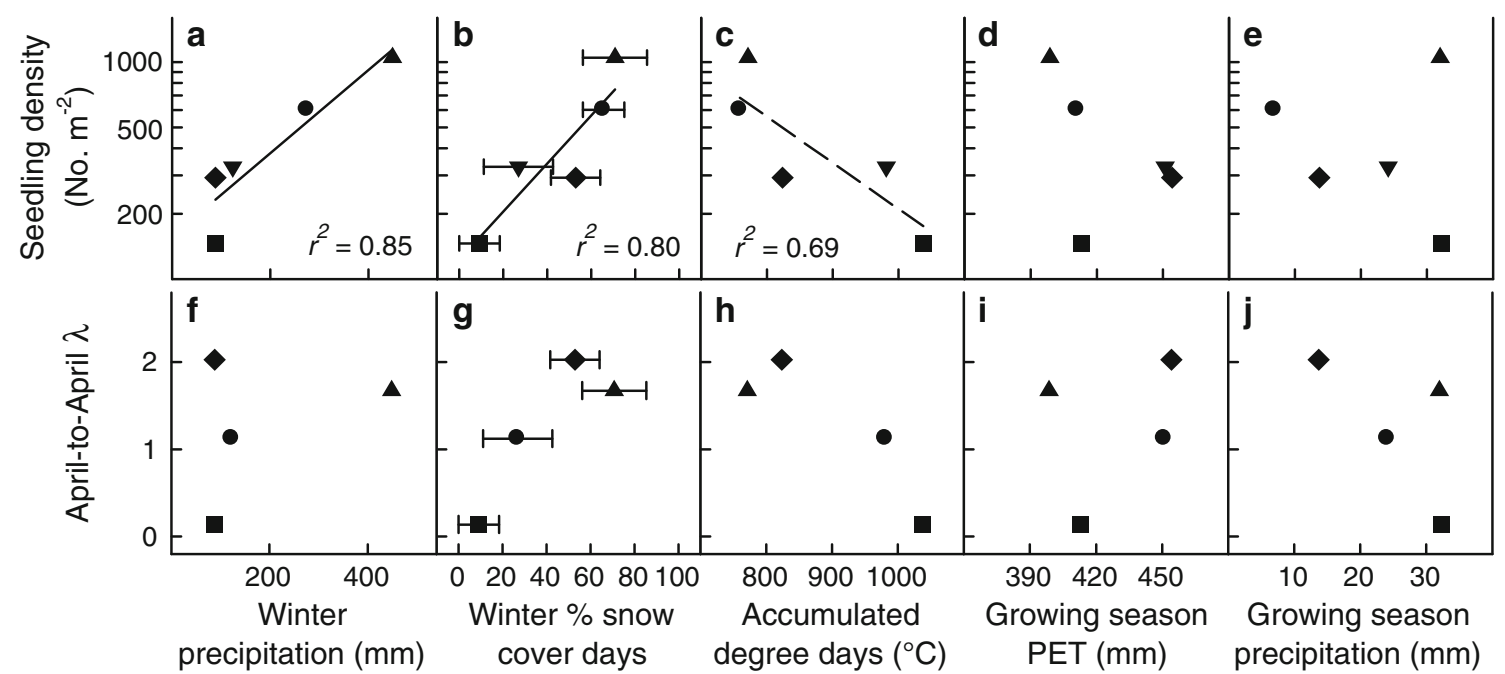

Fig. 5 Relationships between climatic variables and (a-e) mean Bromus tectorum April seedling density and $(\mathbf{f}-\mathbf{j})$ April-to-April $\lambda$ from 2005 to 2009. For seedling density, all climatic variables are antecedent, e.g. the April seedling value for 2005 is related to the climatic conditions of the 2004/2005 winter and the 2004 growing season (a-efilled circle 2005, filled triangle 2006, filled square 2007, filled diamond 2008, inverted triangle 2009). For $\lambda$, both winter and growing season climatic conditions fall within the April-to-April time

$\left(r^{2}=0.76, P=0.125\right.$; Fig. $\left.5 \mathrm{~g}\right)$ and accumulated degreedays $\left(r^{2}=0.79, P=0.113\right.$; Fig. 5 h $)$.

\section{Discussion}

\section{Experimental snow depth manipulation}

Consistent with our original hypothesis, we found a negative effect of experimentally-increased snow depth on $B$. tectorum population growth $(\lambda)$, with $\lambda$ on + snow plots reduced by nearly $50 \%$ of control plots. This period spanned the first winter of snow manipulations (2005/2006) when the snowpack on +snow plots was deeper and of longer duration than any natural snowpack in the study. The effects on individual plants were more nuanced. Smaller plants on +snow plots during the 2006 growing season is indicative of a phenological effect and corresponds with a delay in snow melt of 9 days compared to ambient snow depth plots. However, there was little lasting influence on growth over the next few months, consistent with no strong soil moisture differences among the plots, nor a difference in relative growth rates of individual plants.

Although individual biomass is a good predictor of fecundity for B. tectorum (Griffith 2010), the effect of increased snow on individual biomass was apparently not large enough to generate differences in fecundity by the end of the 2006 growing season (Table 2). This may be a span (f- $\mathbf{- j}$ filled circle 2005-2006, filled triangle 2006-2007, filled square 2007-2008, filled diamond 2008-2009). Winter spans December 1 to April 14 and Growing season April 15 to June 30. Accumulated degree-days were calculated between September 1 and April 14. Snow cover days are expressed as a range based on conservative and less conservative estimates of snow cover from satellite data (see "Methods"). Linear regressions are indicated as statistically significant (solid lines $P<0.05$ ) and marginally significant (dashed lines $P<0.10$ )

result of continued growth and spikelet production on +snow plots after the early June sampling period via a phenological shift lasting through the end of the season. Many studies that have manipulated snow depth and duration report an influence on aspects of plant fecundity, such as flowering time and duration, flowering number, seed production, and/or seed weight (Bell and Bliss 1979; Galen and Stanton 1993; Dunne et al. 2003; Wipf et al. 2006; Lambrecht et al. 2007). However, these effects are often variable among species - both in sign and intensityand demonstrate complicated trade-offs between insulation from harsh winter conditions and a longer growing season as a result of snowpack dynamics. These studies were conducted in alpine/subalpine and arctic/subarctic systems and focused primarily on perennial plant species. It may be difficult to compare the growing-season response of $B$. tectorum near its current upper elevational margin to plants with fundamentally different life histories that have evolved with deep winter snow cover.

In addition to effects on biomass, demographic data from 2006 showed an important negative effect of increased snow depth on early survivorship (Fig. 2b). This result is difficult to interpret as phenologies differed among snow depth treatments. Typical of many plants, B. tectorum at this site follows a type III survivorship curve, with the highest mortality associated with seedling establishment. It is possible that during the April sampling period in 2006, early mortality on + snow plots was ongoing (i.e. seedling establishment was not complete), whereas much of this 
mortality had already occurred on control plots due to shifted phenologies. We believe this is likely given that for $87 \%$ of individuals in + snow plots, only the coleoptile had emerged by the April sampling period. This is in contrast to the control plots where an average of $7 \%$ of individuals consisted only of the coleoptile. Therefore, we cannot meaningfully state that there was a true effect of snow depth on survivorship; rather this value is in part an artifact of shifted phenologies and fixed sampling times.

We were able to partially resolve this issue by combining measures of early survivorship and seedling emergence through population modeling of the entire life cycle. For example, if early survivorship on +snow plots was artifactually reduced, then it is inherently compensated for by artifactually increased emergence, and it then only makes sense to examine the two together. The LTRE analysis demonstrated that the decrease in $\lambda$ on + snow plots was due to the combined reduction in seedling emergence, size, and survivorship (Fig. 2b). We conclude that the negative effect of increased snowpack on $\lambda$ resulted from factors operating during, or immediately following, snow cover and not during the bulk of the growing season.

The implications of confounded sampling dates and phenologies impose analytical challenges. In the context of anthropogenic climate change, it is important not only to document phenological shifts, but to understand how they affect populations and communities (Walther 2004; Cleland et al. 2007). However, demographic analyses for annual organisms, which are useful to this end, require repeated sampling periods. If the effect of interest is phenological, such analyses are difficult to conduct unless sampling is frequent and intervals are extremely short. Alternatively, one could attempt to stagger sampling dates across plots so that they are aligned with phenology. The drawback of this approach is that external effects (e.g., weather or disturbance events) may occur between sampling dates, again introducing artifacts and confounding results.

Across the 5 years of the study (Fig. 3), the only years with any decline in B. tectorum mean density on + snow plots were preceded by winters that produced large snowpacks on +snow plots (2005/2006 and 2007/2008). The snowpack on + snow plots in these years were apparently larger than any naturally occurring snowpacks during the study (Fig. 1) and suggest that only a very substantial snowpack exerts a negative effect on $B$. tectorum populations. In other years when there was no relative decline in B. tectorum density on + snow plots, there was only sporadic snow cover (even on +snow plots). These results highlight the complexity of population-level responses to climatic factors. In particular, populations can have a "memory" of antecedent climatic events such that the effect can be retained for several years, or effects may compound across years and amplify (Schwinning et al. 2004). Changes in the magnitude and duration of the snowpack are also likely to have important effects on soil nutrient dynamics due to altered rates of transformation and/or release (Groffman et al. 2001; Johnson et al. 2009). During the 2 years of detailed demography, we performed limited soil nutrient analyses (Griffith 2010). In April 2006, $\mathrm{NO}_{3}{ }^{-}$availability was slightly higher on + snow plots $(0.89$ vs $\left.0.71 \mathrm{~g} \mathrm{~m}^{-2} ; P=0.063\right)$, but not for $\mathrm{NH}_{4}{ }^{+}$or available $\mathrm{P}$ and $\mathrm{K}$ (nor were there any differences in June 2005). Thus, we have little evidence that snowpack-induced changes in nutrient availability were strongly driving our demographic results.

Natural interannual variability

The large population decline between 2005/2006 and 2006/ 2007 was primarily due to very low rates of seedling emergence/establishment in April 2007 (Fig. 4b). However, all other demographic variables also decreased between these periods with differences in survival, growth, and fecundity contributing to $37 \%$ of the decline in population growth. We will first discuss effects during the growing season ('post-establishment') followed by the major influence of seedling emergence/establishment ("preestablishment'). We will then discuss the possible roles of climatic variables across the 5 years of $B$. tectorum density measurements.

\section{Post-establishment effects}

During the growing season, $B$. tectorum individuals are likely influenced by concurrent growing conditions and by both the timing of snow melt and its influence on soil moisture. A lack of soil moisture differences between 2005 and 2006 suggests that the differential response of B. tectorum was not driven by snowpack-derived soil moisture differences. Indeed, the period of snow depth influence on surface soil moisture may be quite short in this system. Seedling root systems of B. tectorum are not extensive or deep, and access to snowpack-derived soil moisture near the soil surface is likely to quickly diminish through rapid infiltration and evaporation (Loik et al. 2004; Loik 2007).

In contrast to a lack of soil moisture differences, an interannual phenological effect appears likely. April sampling in 2006 began only 3 calendar days later than in 2005, yet it was 27 days after final snow melt compared to 17 days in 2005. A phenological influence of snowpack on interannual biomass differences is consistent with the biomass differences among the experimental snow depth plots in 2006. Phenological effects induced by natural variation in snow melt timing have been shown to have significant effects on plant reproductive success (Walker 
et al. 1995; Inouye et al. 2002). From the data in this study, it is difficult to determine how much of the interannual fecundity difference is attributable to differences in phenology. However, results from the 2006 snow depth manipulations indicate that a slight phenological shift alone may not have a large impact on $B$. tectorum reproduction at this site. Instead slightly lower relative growth rates (RGR) in 2006 suggests that differences in growing-season environmental conditions may have contributed to differences in fecundity between years.

Increased potential evapotranspiration (PET) and reduced precipitation during the early growing season in 2006 could have limited periods of photosynthesis through stomatal closure (Noy-Meir 1973; Fischer and Turner 1978; Aphalo and Jarvis 1991; Tardieu and Simonneau 1998). For example, in the first 6 weeks following snow melt, cumulative PET was $161 \mathrm{~mm}$ in 2006 compared to $128 \mathrm{~mm}$ in 2005. Similarly precipitation during this period totaled $5.05 \mathrm{~mm}$ in 2006 compared to $16.4 \mathrm{~mm}$ in 2005 . Thus, there was greater evaporative demand and less precipitation during the critical period of early seedling growth in 2006. Other factors that could have resulted in the reduced fecundity between 2005 and 2006 include herbivory and/or density-dependent processes, though there was little evidence for either of these. In general, instances of inferred herbivory were very low (less than 5\% of individuals) and did not differ between years (data not shown). Whereas there was some indication of negative density dependence in 2006, the relationship was weak and cannot explain the fecundity differences between 2005 and 2006.

\section{Pre-establishment effects}

Bromus tectorum population growth at this site is extremely sensitive to the rate of seedling establishment (Griffith 2010), and very low emergence/establishment (4\%) in April 2007 primarily contributed to the decrease in population growth between years (Fig. 4b). This may have resulted from germination during a winter with very low snow cover that resulted in substantial early mortality. As a winter annual, B. tectorum seeds may germinate opportunistically between the autumn and spring given appropriate conditions (Young et al. 1969; Young and Evans 1975; Mack and Pyke 1983; Mack and Pyke 1984). The accumulated number of degree-days (above $0^{\circ} \mathrm{C}$ ) has been shown to be an important predictor of B. tectorum germination (Roundy et al. 2007). Beginning in September, total snow-free degree-days was 771 by April 2006 compared to 1,037 by April 2007, while 771 degree-days had already been accumulated by early February 2007, suggesting that seeds may have been capable of germinating throughout the 2006/2007 winter when there was little snow cover.
This indeed seems likely from the two clear seedling size classes seen in April 2007, when less than 2\% of individuals were substantially larger than any seedlings previously encountered. From this observation, we infer that there were at least two seedling cohorts during the 2006/2007 winter, with the vast majority of surviving seedlings in the youngest cohort. Winter-time germination at this elevation may be detrimental and may reveal a positive influence of snow cover, by which it limits germination until conditions for survival are more favorable.

\section{Long-term density}

The 5-year B. tectorum density dataset suggests that winter-time climatic factors may be more important than growing season factors at this location (Fig. 5). Although 5 years of data ( 4 for values of $\lambda$ ) likely represents the minimum necessary to draw any conclusions from interannual climatic variability, the main results are consistent with those of the 2005-2007 detailed demography dataset discussed above: winters with greater snow cover and a slower accumulation of degree-days coincide with higher B. tectorum seedling density and population growth. This is in contrast to our original hypothesis, and indeed may be entirely opposite at lower elevations where winter-time germination may be favorable.

Of course, seedling density can never be predicted by climatic variables alone as prior seed production must be important. Although we do not have seed production data for all years, similar mean seed production in June 2005 and $2006\left(6,465\right.$ vs 5,159 seeds $\left.\mathrm{m}^{-2}, P=0.839\right)$ was respectively followed by the highest $\left(1,048\right.$ seedlings $\left.\mathrm{m}^{-2}\right)$ and lowest (146 seedlings $\mathrm{m}^{-2}$ ) April seedling densities in the study, indicating that climatic factors can likely overwhelm propagule supply.

\section{Synthesis}

Our original hypothesis of a negative effect of snowpack on B. tectorum populations was supported from an experimentally-increased snowpack in some years, yet relationships between natural variability in wintertime snow cover and B. tectorum populations were positive. These results are not necessarily in conflict with each other. Rather, they indicate that our original hypothesis was likely too simplistic and that the effects of the snowpack may be nonlinear at high elevation. Our hypothesis was largely based on previous $B$. tectorum demographic research (Mack and Pyke 1983, 1984; Pierson and Mack 1990a) that found high winter mortality in certain years. We hypothesized that winters at our high-elevation site adjacent to the Sierra Nevada would be much more severe (compared to the previous research 
below $1,000 \mathrm{~m}$ ) and would represent a constraint on B. tectorum demography. However, a particular winter is only severe if seedlings have emerged to experience it. Similar to alpine and subalpine systems, B. tectorum populations may benefit from a continuous snowpack at higher elevation that serves as a barrier to germination when exposure to severe conditions is likely.

Modeled scenarios of anthropogenic climate change in eastern California project increased temperatures, rising snowlines, and reduced winter snowpack during this century (Hayhoe et al. 2004; Leung et al. 2004; Snyder and Sloan 2005; Cayan et al. 2008). With decreased snow cover, the direct consequences of climate change for $B$. tectorum at high elevation may depend on temperature and weather events during increasingly frequent snow-free periods. Whereas snow-free periods amid current climatic conditions may present challenges to B. tectorum establishment at high elevations, a future reduction in winter diel temperature range and higher daily minimum temperatures (Leung et al. 2004) could enhance establishment during these periods. Mack and Pyke (1983) observed that the fecundity of B. tectorum individuals that survived the winter was consistently and substantially greater than those that germinated in the spring. Thus, if a future climate increases survivorship of recruits during the winter period at high elevation, seed output could be multiplicatively increased, limiting the number of years in which $\lambda<1$.

It is difficult to predict whether the invasion of $B$. tectorum will advance upwards into the Sierra Nevada under future climate change scenarios. At elevations not much above our study site, factors associated with the Sierran conifer forest will likely become important. Pierson and Mack (1990a) reported that $B$. tectorum seeds experimentally introduced into Washington and Idaho forests $(<1,000 \mathrm{~m})$ germinated in the autumn, suffered high wintertime mortality, and often failed to reproduce. They attributed this mainly to altered environmental conditions in the forest including shading, reduced temperatures, and greater snowpack. Our study has demonstrated that while population dynamics are variable, B. tectorum is capable of rapid population growth, with 3 years exhibiting annual seedling density increases of 12, 67, and $103 \%$. However, as dispersal into Sierran forests is already likely, the general lack of B. tectorum there suggests that mechanisms associated with the forest (e.g., shading, litter, herbivory, soil quality) are currently restricting B. tectorum (Pierson and Mack 1990b).

Overall, the results of this study suggest that the response of B. tectorum to high elevation snowpack is likely nonlinear and differs from that at lower elevation. In particular, effects on seedling emergence and early survival can have a tremendous impact on population growth. Regardless, B. tectorum is capable of both rapid population growth and decline at high elevation. From a management standpoint, a doubling of population size in 1 year is alarming at this elevation. Although, we cannot yet state the frequency of 'boom' and 'bust' years, it is possible that several 'boom' years in a row could result in a rapid increase in B. tectorum biomass - and hence fuel load-along the eastern Sierra.

Acknowledgments We thank Holly Alpert, Amy Concilio, and Katie Griffith for fieldwork assistance, and Michael Kennedy, Isabel Schmidt, and Alexandre Sampaio for help with snow fence construction. Daniel Dawson and the entire staff of the U.C. Valentine Eastern Sierra Reserve provided invaluable support and assistance with lodging and logistics. Ingrid M. Parker, Daniel F. Doak, Julie Beckstead, Richard Lucas, Kristina Niovi Jones, and several anonymous reviewers provided helpful comments and suggestions that greatly improved this manuscript. Financial support for this study was provided by the STEPS Institute for Innovation in Environmental Research, the UCSC Environmental Studies Department, the Mildred E. Mathias Graduate Student Research Grant, the Valentine Eastern Sierra Reserve Graduate Student Research Grant, the David Gaines Memorial Award, and a California Native Plant Society (Bristlecone Chapter) Educational Grant. This research was conducted with permission of the United States Forest Service.

Open Access This article is distributed under the terms of the Creative Commons Attribution Noncommercial License which permits any noncommercial use, distribution, and reproduction in any medium, provided the original author(s) and source are credited.

\section{References}

Allen RG, Pereira LS, Raes D, Smith M (1998) Crop evapotranspiration: guidelines for computing crop water requirements. FAO, Rome

Aphalo PJ, Jarvis PG (1991) Do stomata respond to relative humidity. Plant Cell Environ 14:127-132

Beckstead J, Meyer SE, Allen PS (1996) Bromus tectorum seed germination: between-population and between-year variation. Can J Bot 74:875-882

Bell KL, Bliss LC (1979) Autecology of Kobresia bellardii-why winter snow accumulation limits local distribution. Ecol Monogr 49:377-402

Billings WD (1990) Bromus tectorum, a biotic cause of ecosystem impoverishment in the Great Basin. In: Woodell GM (ed) The earth in transition: patterns and processes of biotic impoverishment. Cambridge University Press, Cambridge

Billings WD, Bliss LC (1959) An apline snowbank environment and its effects on vegetation, plant development, and productivity. Ecology 40:388-397

BLM (2000) The Great Basin: healing the land. Bureau of Land Management (BLM), US Department of the Interior

Caswell H (2001) Matrix population models: construction, analysis, and interpretation, 2nd edn. Sinauer, Sunderland

Cayan DR, Maurer EP, Dettinger MD, Tyree M, Hayhoe K (2008) Climate change scenarios for the California region. Clim Change 87:S21-S42

Chambers JC, Roundy BA, Blank RR, Meyer SE, Whittaker A (2007) What makes Great Basin sagebrush ecosystems invasible by Bromus tectorum? Ecol Monogr 77:117-145

Cleland EE, Chuine I, Menzel A, Mooney HA, Schwartz MD (2007) Shifting plant phenology in response to global change. Trends Ecol Evol 22:357-365 
D'Antonio CM, Vitousek PM (1992) Biological invasions by exotic grasses, the grass/fire cycle, and global change. Annu Rev Ecol Syst 23:63-87

Dukes JS, Mooney HA (1999) Does global change increase the success of biological invaders? Trends Ecol Evol 14:135-139

Dunne JA, Harte J, Taylor KJ (2003) Subalpine meadow flowering phenology responses to climate change: integrating experimental and gradient methods. Ecol Monogr 73:69-86

Fischer RA, Turner NC (1978) Plant productivity in arid and semiarid zones. Ann Rev Plant Physiol Plant Mol Biol 29:277-317

Galen C, Stanton ML (1993) Short-term responses of alpine buttercups to experimental manipulations of growing-season length. Ecology 74:1052-1058

Griffith AB (2010) Positive effects of native shrubs on Bromus tectorum demography. Ecology 91:141-154

Groffman PM, Driscoll CT, Fahey TJ, Hardy JP, Fitzhugh RD, Tierney GL (2001) Effects of mild winter freezing on soil nitrogen and carbon dynamics in a northern hardwood forest. Biogeochemistry 56:191-213

Hayhoe K, Cayan D, Field CB, Frumhoff PC, Maurer EP, Miller NL, Moser SC, Schneider SH, Cahill KN, Cleland EE, Dale L, Drapek R, Hanemann RM, Kalkstein LS, Lenihan J, Lunch CK, Neilson RP, Sheridan SC, Verville JH (2004) Emissions pathways, climate change, and impacts on California. Proc Natl Acad Sci USA 101:12422-12427

Hunt R (1978) Plant growth analysis. Edward Arnold, London

Inouye DW, Morales MA, Dodge GJ (2002) Variation in timing and abundance of flowering by Delphinium barbeyi Huth (Ranunculaceae): the roles of snowpack, frost, and La Niña, in the context of climate change. Oecologia 130:543-550

Jackson LE, Bliss LC (1984) Phenology and water relations of three plant life forms in a dry tree-line meadow. Ecology 65:1302-1314

Johnson DW, Miller WW, Susfalk RB, Murphy JD, Dahlgren RA, Glass DW (2009) Biogeochemical cycling in forest soils of the Eastern Sierra Nevada mountains, USA. For Ecol Manage 258:2249-2260

Klanderud K, Birks HJB (2003) Recent increases in species richness and shifts in altitudinal distributions of Norwegian mountain plants. Holocene 13:1-6

Knapp PA (1996) Cheatgrass (Bromus tectorum L) dominance in the Great Basin Desert-history, persistence, and influences to human activities. Glob Environ Change Hum Policy Dimens 6:37-52

Lambrecht SC, Loik ME, Inouye DW, Harte J (2007) Reproductive and physiological responses to simulated climate warming for four subalpine species. New Phytol 173:121-134

Leung LR, Qian Y, Bian XD, Washington WM, Han JG, Roads JO (2004) Mid-century ensemble regional climate change scenarios for the Western United States. Clim Change 62:75-113

Loik ME (2007) Sensitivity of water relations and photosynthesis to summer precipitation pulses for Artemisia tridentata and Purshia tridentata. Plant Ecol 191:95-108

Loik ME, Breshears DD, Lauenroth WK, Belnap J (2004) A multiscale perspective of water pulses in dryland ecosystems: climatology and ecohydrology of the western USA. Oecologia 141:269-281

Mack RN, Pyke DA (1983) The demography of Bromus tectorumvariation in time and space. J Ecol 71:69-93

Mack RN, Pyke DA (1984) The demography of Bromus tectorumthe role of microclimate, grazing and disease. J Ecol 72:731-748

Manly BFJ (1997) Randomization, bootstrap and Monte Carlo methods in biology, 2nd edn. Chapman \& Hall, New York

Meyer SE, Allen PS, Beckstead J (1997) Seed germination regulation in Bromus tectorum (Poaceae) and its ecological significance. Oikos 78:475-485

Noy-Meir I (1973) Desert ecosystems: environment and producers. Annu Rev Ecol Syst 4:25-51
Parmesan C (2006) Ecological and evolutionary responses to recent climate change. Annu Rev Ecol Evol Syst 37:637-669

Parmesan C, Yohe G (2003) A globally coherent fingerprint of climate change impacts across natural systems. Nature 421:37-42

Pauchard A, Kueffer C, Dietz H, Daehler CC, Alexander J, Edwards PJ, Arevalo JR, Cavieres LA, Guisan A, Haider S, Jakobs G, McDougall K, Millar CI, Naylor BJ, Parks CG, Rew LJ, Seipel T (2009) Ain't no mountain high enough: plant invasions reaching new elevations. Frontiers Ecol Environ 7:479-486

Pauli H, Gottfried M, Reier K, Klettner C, Grabherr G (2007) Signals of range expansions and contractions of vascular plants in the high Alps: observations (1994-2004) at the GLORIA*master site Schrankogel, Tyrol, Austria. Glob Change Biol 13:147-156

Pierson EA, Mack RN (1990a) The population biology of Bromus tectorum in forests-distinguishing the opportunity for dispersal from environmental restriction. Oecologia 84:519-525

Pierson EA, Mack RN (1990b) The population biology of Bromus tectorum in forests-effect of disturbance, grazing, and litter on seedling establishment and reproduction. Oecologia 84:526-533

Root TL, Price JT, Hall KR, Schneider SH, Rosenzweig C, Pounds JA (2003) Fingerprints of global warming on wild animals and plants. Nature 421:57-60

Roundy BA, Hardegree SP, Chambers JC, Whittaker A (2007) Prediction of cheatgrass field germination potential using wet thermal accumulation. Rangel Ecol Manag 60:613-623

Schwinning S, Sala OE, Loik ME, Ehleringer JR (2004) Thresholds, memory, and seasonality: understanding pulse dynamics in arid/ semi-arid ecosystems. Oecologia 141:191-193

Simberloff D (2000) Global climate change and introduced species in united states forests. Sci Total Environ 262:253-261

Smith B, Mark AF, Wilson JB (1995) A functional analysis of New Zealand alpine vegetation: variation in canopy roughness and functional diversity in response to an experimental wind barrier. Funct Ecol 9:904-912

Snyder MA, Sloan LC (2005) Transient future climate over the Western United States using a regional climate model. Earth Interact 9:1-21

Tabler RD (1991) Snow fence guide. Strategic Highway Research Program. National Research Council, Washington, DC

Tabler RD (1994) Design guidelines for the control of blowing and drifting snow. Strategic Highway Research Program. National Research Council, Washington, DC

Tardieu F, Simonneau T (1998) Variability among species of stomatal control under fluctuating soil water status and evaporative demand: modelling isohydric and anisohydric behaviours. J Exp Bot 49:419-432

Theoharides KA, Dukes JS (2007) Plant invasion across space and time: factors affecting nonindigenous species success during four stages of invasion. New Phytol 176:256-273

Walker MD, Ingersoll RC, Webber PJ (1995) Effects of interannual climate variation on phenology and growth of two alpine forbs. Ecology 76:1067-1083

Walther GR (2000) Climatic forcing on the dispersal of exotic species. Phytocoenologia 30:409-430

Walther GR (2004) Plants in a warmer world. Perspect Plant Ecol Evol Syst 6:169-185

Walther GR, Post E, Convey P, Menzel A, Parmesan C, Beebee TJC, Fromentin JM, Hoegh-Guldberg O, Bairlein F (2002) Ecological responses to recent climate change. Nature 416:389-395

Wipf S, Rixen C, Mulder CPH (2006) Advanced snowmelt causes shift towards positive neighbour interactions in a subarctic tundra community. Glob Change Biol 12:1496-1506

Young JA, Evans RA (1975) Germinability of seed reserves in a big sagebrush community. Weed Sci 23:358-364

Young JA, Evans RA, Eckert RE (1969) Population dynamics of downy brome. Weed Sci 17:20-26 